\title{
Relationship between the Serum IgA/C3 Ratio and the Progression of IgA Nephropathy
}

Key words: serum IgA/C3 ratio, prognosis, IgA nephropathy

IgA nephropathy (also called Berger's disease) is a common form of chronic glomerulonephritis throughout the world and is clinically characterized by microscopic hematuria and/or proteinuria. IgA nephropathy is generally presumed to be $\operatorname{IgA}$ immune complex or polymerized IgAmediated glomerulonephritis (1). IgA may play an important role in the pathogenesis and development of IgA nephropathy. Several investigators reported that serum IgA is significantly increased in patients with the disease (1). Since elevated serum IgA levels are valuable in the diagnosis of this disease, it is important to quantitate precise amounts of serum IgA in patients with various types of chronic glomerulonephritis. In 1997, the international reference preparation, CRM 470 produced by IFCC, was introduced in Japan (2). The new criterion for IgA nephropathy obtained by nephelometric immunoassay based on the international reference preparation CRM 470 was $315 \mathrm{mg} / \mathrm{dl}$ (3). The serum IgA levels were internationally standardized based on evidence.

Ishiguro et al (4) reported that the levels of serum $\operatorname{IgA}$ and C3 in patients with IgA nephropathy and other glomerular diseases were adjusted by a special formula to those using international standard serum (IFCC/CRM470). The results showed the highest serum $\operatorname{IgA} / \mathrm{C} 3$ ratio in patients with $\operatorname{IgA}$ nephropathy. The serum IgA/C3 ratio appears to gradually increase according to the prognostic grading of this disease (4). Recently, Komatsu et al (5) studied the serum IgA/C3 ratio, using a standard reference material, in 86 patients with IgA nephropathy and in 32 patients with non-IgA nephropathy.

See also p 1023.

The serum IgA level was significantly higher, while the C3 level was lower in patients with severe $\operatorname{IgA}$ nephropathy compared to those with non-IgA nephropathy. Kaplan-Meier analysis of the patients with IgA nephropathy classified according to the mean serum $\mathrm{IgA} / \mathrm{C} 3$ ratio revealed that the group with high serum IgA/C3 ratios (4.5 and above) had significantly poorer renal outcome since the cumulative renal survival rate at five years was $84.4 \%$ vs $100 \%$ (6). It appears that measurement of serum $\operatorname{IgA}$ to $\mathrm{C} 3$ (serum $\mathrm{IgA} / \mathrm{C} 3$ ratio) ratio may be useful for the prediction of the diagnosis and prognostic grading in patients with IgA nephropathy.

$\operatorname{IgA}$ nephropathy is definitely diagnosed by glomerular mesangial deposition of IgA (mainly IgA1) in renal biopsy specimens as determined by immunohistochemistry. The indicative criteria for renal biopsy used in our division are as follows: presence of persistent proteinuria with or without microscopic hematuria, and an almost normal range of renal function. Maeda et al (6) performed an analysis to distinguish between IgA nephropathy and non-IgA nephropathy using four clinical markers: 1) more than five red blood cells in urinary sediments, 2) persistent proteinuria (urinary protein of more than $0.3 \mathrm{~g} /$ day), 3) serum IgA levels of more than $315 \mathrm{mg} / \mathrm{dl}$, and 4) a serum $\operatorname{IgA} / \mathrm{C} 3$ ratio of more than 3.01. It also appears that three or four clinical markers are useful for distinguishing IgA nephropathy from other primary renal diseases. It is postulated that these clinical markers are useful for the diagnosis of IgA nephropathy without renal biopsy.

$$
\begin{array}{r}
\text { Yasuhiko TOMINO, MD } \\
\text { Division of Nephrology, Department of Internal Medicine, } \\
\text { Juntendo University School of Medicine, } \\
\text { 2-2-1 Hongo, Bunkyo-ku, Tokyo 113-8421 }
\end{array}
$$

\section{References}

1) Tomino Y. IgA nephropathy from molecules to men. Contrib Nephrol 126:1-115, 1999.

2) Itoh $Y$, Ichihara $K$, Kanno $T$, et al. Serum protein standardization project in Japan: Evaluation of an IFCC reference material (RPPHS/ CRM470) and establishment of reference intervals. J Clin Lab Anal 11: 39-44, 1997.

3) Tomino Y, Suzuki S, Imai H, et al. Measurement of serum IgA and C3 may predict the diagnosis of patients with IgA nephropathy prior to renal biopsy. J Clin Lab Anal 14: 220-223, 2000.

4) Ishiguro $C$, Yaguchi Y, Funabiki K, Horikoshi S, Shirato I, Tomino Y. Serum IgA/C3 ratio may predict diagnosis and prognostic grading in patients with IgA nephropathy. Nephron 91: 755-758, 2002.

5) Komatsu H, Fujimoto S, Hara S, Sato Y, Yamada K, Eto T. Relationship between serum IgA/C3 ratio and progression of IgA nephropathy. Intern Med 43: 1023-1028, 2004.

6) Maeda A, Gohda T, Funabiki K, Horikoshi S, Shirato I, Tomino Y. Significance of serum IgA levels and serum $\mathrm{IgA} / \mathrm{C} 3$ ratio in diagnostic analysis of patients with IgA nephropathy. J Clin Lab Anal 17: 73-76, 2003. 